\title{
Regulation of gonadotrophin-releasing hormone secretion by testosterone in male sheep
}

\author{
S. M. Hileman ${ }^{1}$ and G. L. Jackson ${ }^{2}$ \\ 'Department of Medicine, Division of Endocrinology, Beth Israel Deaconess Medical Center, \\ Harvard Medical School, Boston, MA 02215, USA; ${ }^{2}$ Department of Veterinary Biosciences, \\ University of Illinois, Urbana, IL 61802, USA
}

\begin{abstract}
In males, including the ram, testosterone, acting via its primary metabolites oestradiol and dihydrotestosterone (DHT), suppresses circulating LH concentrations. This effect is due primarily, although not totally, to decreased frequency of gonadotrophin-releasing hormone (GnRH) pulses. The arcuate-ventromedial region (ARC-VMR) of the mediobasal hypothalamus and possibly the medial preoptic area (mPOA) are sites at which oestradiol acts to suppress GnRH, but the site of DHT action is not known. Given that native $\mathrm{GnRH}$ neurones appear to contain few or no oestrogen or androgen receptors, the effects of testosterone metabolites probably are exerted by modulating activity of inhibitory interneurone systems such as $\beta$-endorphin, dopamine, and $\gamma$ aminobutyric acid (GABA). Although $\beta$-endorphin clearly inhibits GnRH secretion, the observation that testosterone treatment during a long-day photoperiod reduced proopiomelanocortin (POMC) mRNA in the arcuate nucleus while coincidentally suppressing $\mathrm{GnRH}$ release indicates that $\beta$-endorphin does not mediate the inhibitory effect of testosterone on GnRH. Activation of GABA receptors in either the mPOA or ARC-VMR suppressed $\mathrm{LH}$, whereas activation of $\mathrm{GABA}_{\mathrm{B}}$ receptors in the ARC-VMR increased LH pulse amplitude. Therefore, it is suggested that GABA acts in both regions to regulate $\mathrm{LH}$. Whereas testosterone affects GABA metabolism in the rat hypothalamus, its effect in the ram hypothalamus is yet to be determined. Testosterone treatment activated dopaminergic cells in the retrochiasmatic A15 area in the same animals in which it suppressed POMC mRNA in the arcuate nucleus. This dopaminergic system may partially mediate the negative feedback effect of testosterone in the ram analogous to its role in partially mediating the negative effect of oestrogen in the ewe. Future studies must concentrate on determining how these and other putative inhibitory neuronal systems interact and how they in turn are regulated by environmental factors such as photoperiod.
\end{abstract}

\section{Introduction}

Upon casual observation it may be concluded that there is a relatively simple relationship among the secretory patterns of reproductive hormones in the male. A pulse of GnRH released from the hypothalamus releases a pulse of LH from the pituitary, which in turns elicits a burst of testosterone secretion from the testis. The increased testosterone then suppresses $\mathrm{GnRH}$ and $\mathrm{LH}$, completing a typical negative feedback loop. Although it is correct, this simple depiction belies a far more complex relationship. Closer observation reveals that the feedback loop has many components and that the relationships between those components are highly dynamic, being influenced by factors such as age, photoperiod, nutritional status, and social cues. The objective of this review is to describe some of those components, how their function is modulated, and how they affect the efficacy by which testosterone regulates GnRH and LH secretion in one representative animal, the ram, 


\section{Is Metabolism of Testosterone Important?}

Testosterone treatment reduces LH secretion in males of all species studied so far (Kalra and Kalra, 1989). Several observations indicate that this inhibitory effect of testosterone is mediated primarily by the testosterone metabolites oestrogen and DHT rather than testosterone per se. First, very much smaller amounts of oestrogen or DHT than testosterone are necessary for suppression of LH release (Parrott and Davies, 1979). Second, both oestrogen and DHT are produced by peripheral (Hileman et al., 1994) and neuronal aromatization and reduction (Naftolin and Ryan, 1975; Selmanoff et al., 1977) of testosterone. Third, immunization of intact rams against oestrogen greatly increases circulating concentrations of both LH and testosterone (Monet-Kuntz et al, 1988). This result could be due to neutralization of oestrogen produced by the testis as well as oestrogen produced by aromatization from testosterone. However, the observation that treatment of testosterone-treated gonadectomized rams with the aromatase inhibitor aminoglutethimide also significantly increases circulating LH (Scanbacher, 1984) provides strong evidence that oestrogen produced by aromatization from testosterone contributes significantly to normal negative feedback.

Although it was clear that administration of DHT inhibited LH release and blocked a postcastration rise in LH secretion, it was not clear whether conversion of testosterone to DHT is an essential component by which testosterone suppresses LH release. To investigate this question, we infused wethers for $72 \mathrm{~h}$ with either testosterone alone, reductase inhibitor alone (L-651-723 supplied by Merck Research Laboratory, Rahway, NJ), or testosterone together with reductase inhibitor (Hileman et al., 1994b). Infusion of inhibitor alone had no effect on either LH secretion or circulating concentrations of testosterone, oestrogen or DHT. In the testosterone-infused males, reduced LH release was associated with increased concentrations of all three steroid hormones. Infusion of the inhibitor with testosterone blocked only DHT formation (by over $80 \%$ ) and significantly reduced, but did not completely abolish, the ability of testosterone to inhibit LH secretion (Fig. 1). These data led to the suggestion that formation of DHT is an important step in testosterone-induced reduction of pulsatile LH release. Notably, the effect of blocking both aromatase and reductase activity in testosterone-treated castrated rams has not been reported. Given the results of the cited studies, a severe or perhaps total attenuation of testosterone action on LH secretion could be expected.

\section{Site of Testosterone Action on LH}

Although the inhibitory action of testosterone on LH release is clearly established, the specific sites of action of testosterone are only partially known. Whether testosterone reduces GnRH secretion, responsiveness of the pituitary to $\mathrm{GnRH}$, or both, remains unclear for some species (Kalra and Kalra, 1989). In sheep, testosterone acts primarily, although not exclusively, on the brain to suppress GnRH pulse frequency. Specifically, castration leads to increased GnRH pulse frequency (Caraty and Locatelli, 1988), whereas testosterone replacement reduces GnRH pulse frequency (Jackson et al., 1991; Tilbrook and Clarke, 1995). Circulating testosterone, at concentrations that severely reduced GnRH pulse frequency, had a marginal effect on pituitary response to exogenous GnRH (Jackson et al., 1991). However, evaluation of pituitary responsiveness across the annual breeding season leads to the conclusion that testosterone also acts directly on the pituitary to modulate the response to GnRH (Rhim et al, 1993). The neural sensitivity to the negative feedback action of testosterone as well as circulating concentrations of testosterone vary greatly with stage of the annual reproductive cycle (for example, Rhim et al, 1993). Thus it is likely that the relative effect of testosterone on the pituitary versus brain also varies with stage of the annual reproductive cycle.

The specific neural sites at which testosterone or testosterone metabolites act to regulate LH are poorly established. Both oestrogen receptor $\alpha$ and androgen receptor distribution in the sheep brain have been described (Lehman et al., 1993; Herbison, 1995). Within the hypothalamus there are high concentrations of oestrogen receptor $\alpha$ and androgen receptor in the preoptic area, arcuate and ventromedial nucleus, and median eminence. Recently, another form of the oestrogen receptor, 

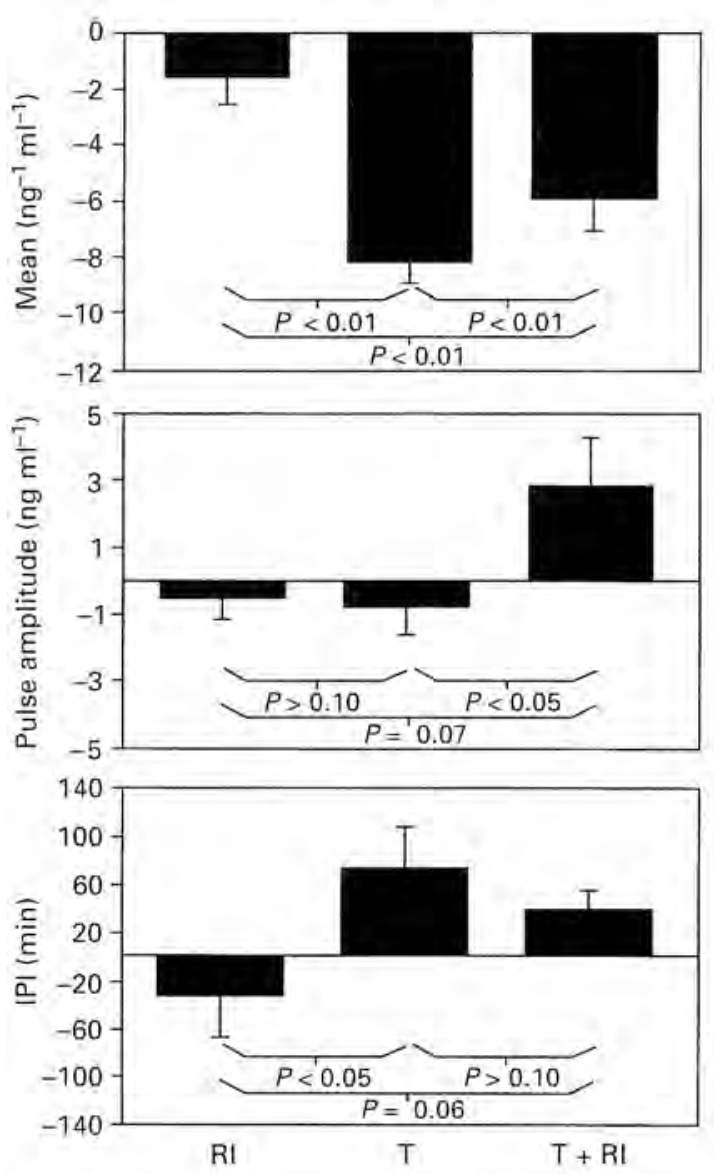

Fig. 1. Changes in LH pulse parameters of castrated male sheep treated with either $0.6 \mathrm{mg} \mathrm{kg}^{-1} 5 \alpha$-reductase inhibitor (RI) $\mathrm{L}-651,723$ or $768 \mathrm{\mu g} \mathrm{kg}^{-1}$ day $^{-1}$ testosterone (T), or $T+$ RI for 3 days. IPI: interpulse interval. Bars represent means \pm SEM of day 3 values minus day 0 values ( $n=5$ per treatment), $P$ values are indicated within each graph for comparisons made between groups using tests of least significant differences. (Reproduced from Hileman et al., 1994 with permission.)

oestrogen receptor $\beta$, has been found. Although the function of oestrogen receptor $\beta$ is not clear, its distribution in the male sheep hypothalamus is similar to that described for the rodent (Shugrue et al, 1997) with localization in the medial preoptic area, retrochiasmatic area, bed nucleus stria terminalis, paraventricular nucleus, supraoptic nucleus and dorsomedial hypothalamus. Only sparse labelling for oestrogen receptor $\beta$ is found in the arcuate nucleus and ventromedial hypothalamus (S. M. Hileman and R. J. Handa, unpublished). Thus, each of these sites, as well as others in the brainstem and amygdala, may be involved in mediating the action of testosterone on GnRH secretion.

In an attempt to delineate specific sites at which testosterone, oestrogen, and DHT act to 
suppress LH, we (Scott et al., 1997) placed implants of these steroids into the MPOA and ARC-VMR of the ventromedial hypothalamus of long-term castrated rams. Implants of testosterone and DHT at either site were ineffective at suppressing LH. In contrast, implants of oestrogen in the mPOA were marginally effective whereas implants of oestrogen into the ARC-VMR clearly suppressed LH (Fig. 2). These results implicate the ARC-VMR as an important site at which oestrogen acts to suppress LH secretion. The reason for the failure of testosterone and DHT implants to suppress LH is not clear, but may reflect less efficient diffusion, downregulation of androgen receptors following castration (Handa et al., 1996), or the fact that androgens may act at other or additional untested sites.

\section{By Which Neural Pathways Does Testosterone Act?}

The specific mechanisms by which testosterone or its metabolites act to suppress GnRH release are not clear. The most parsimonious mechanism would be action of the steroids directly on GnRH neurones. Recent observations indicating that immortalized GT1-7 GnRH-secreting cells contain both androgen and oestrogen receptors support this contention (Belsham et al., 1998; Shen et al., 1998). However, it is debatable whether these cells are fully representative of endogenous GnRH secreting cells in vivo. In addition, it is notable that several investigations have found few or no steroid receptors on native GnRH cells in vivo (Shivers et al, 1983; Huang and Harlan, 1993; Lehman and Karsch, 1993). Consequently, the prevailing hypothesis is that steroids affect GnRH neurones through actions on interneurones. This idea gains support by observations that numerous neurotransmitter agonists and antagonists affect $\mathrm{GnRH}$ secretion and that severaI neuronal systems concentrate gonadal steroids. Under this concept, steroids could reduce GnRH secretion either by increasing secretion of inhibitory neurotransmitters or by reducing secretion of stimulatory neurotransmitters or by a combination of effects. Owing to the inherent difficulty of such studies, relatively little effort has been given to investigating the second or third possibilities. The first possibility is perhaps the easiest to address and results of several studies lead to the suggestion that gonadal steroids modulate the secretion of at least three neurotransmitters known to inhibit LH secretion: opiates (i.e. $\beta$-endorphin), dopamine, and $\gamma$-aminobutyric acid (GABA).

\section{B-Endorphin}

$\beta$-Endorphin neurones are found in high concentrations in the arcuate nucleus, contain oestrogen receptors, and contact GnRH neurones (Leranth et al., 1988; Thind and Goldsmith, 1988; Barb et al., 1991; Lehman and Karsch, 1993). Numerous data show that administration of the opiate agonist morphine suppresses LH, whereas injection of antagonists such as naloxone increases LH (see Barb et al., 1991). Observations that the effects of opiate antagonists are much more robust in intact or testosterone-treated than in castrated animals led to the concept that opiates may mediate the inhibitory action of testosterone (Ebling and Lincoln, 1985; Barb et al., 1991). The observation that peripheral concentrations of $\beta$-endorphin were highest during the breeding season (Ssewannyana and Lincoln, 1990) indicates that the influence of endorphin is greatest during that period. Intuitively, this seems inconsistent with the fact that testosterone is relatively ineffective at inhibiting GnRH release at this time. To investigate this issue further, we performed a series of experiments (Hileman et al., 1996; Hileman et al., 1998) to examine the effect of testosterone on POMC mRNA in the arcuate nucleus under the assumption that amounts of the precursor mRNA may reflect the synthesis and secretion of the peptide. In the most recent study, males were either castrated or castrated and implanted with testosterone, and then placed under either an inhibitory long-day or stimulatory short-day photoperiod. Testosterone did not alter either L.H release or amounts of POMC mRNA in animals exposed to short days. In contrast, testosterone greatly reduced both mean LH concentrations and the amount of POMC mRNA (Fig. 3), but not of GnRH mRNA, in animals exposed to long days (Fig. 3). This finding was consistent with our previous report (Hileman $e t$ al., 1996) that testosterone administered for either 3 days or 3 months reduced POMC mRNA in the 

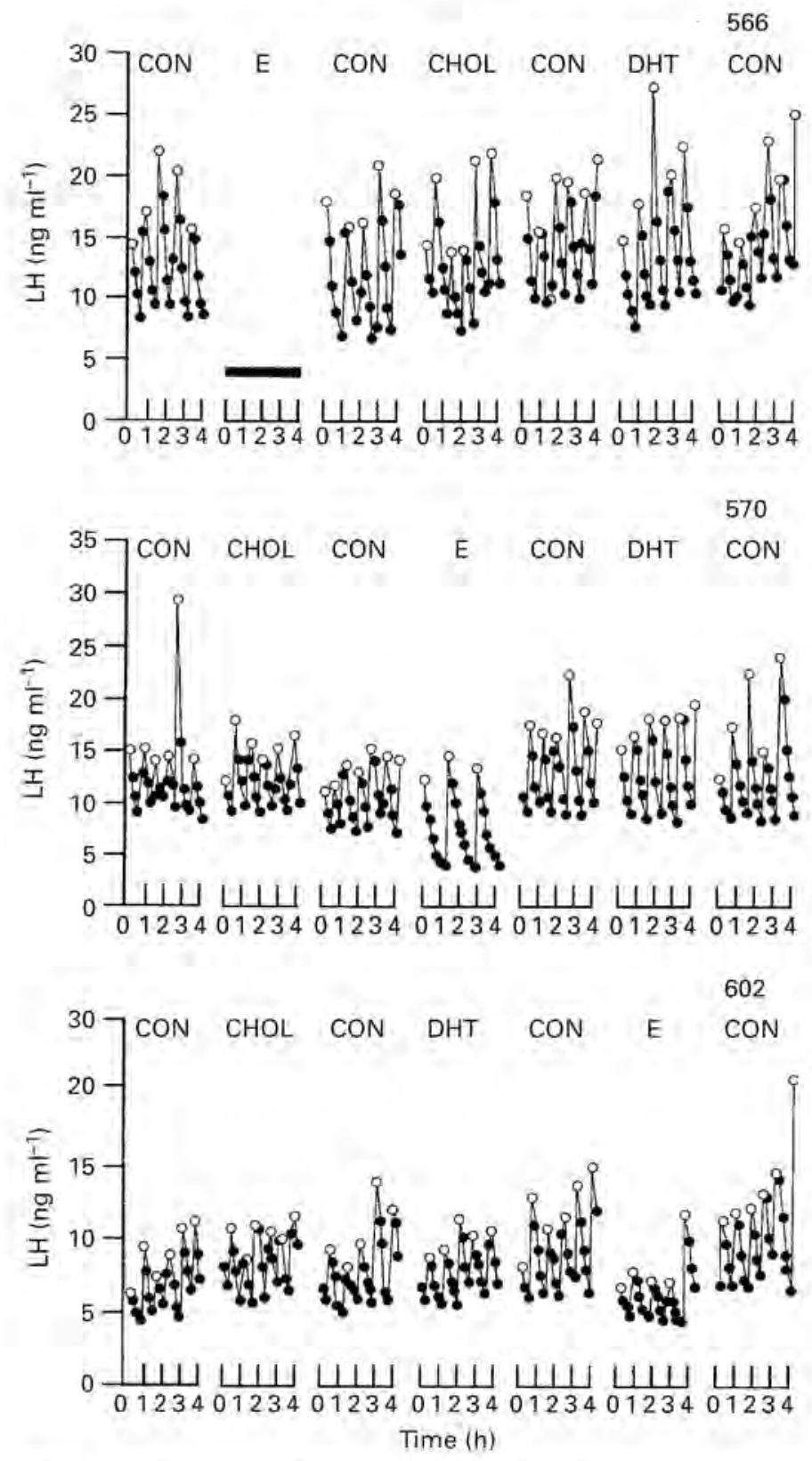

Fig. 2. Examples of LH secretory profiles in plasma of three castrated rams with either stylets or steroid implants placed bilaterally into a site located dorsal-lateral to the arcuate nucleus and medial to the ventromedial nucleus of the hypothalamus. (VMH). CON: stylet; CHOL: cholesterol; DHT: dihydrotestosterone; E: oestradiol. Peaks of $\mathrm{LH}$ pulses are represented by hollow circles. Sampling periods were 7 days apart. The number in the upper right of each panel refers to an individual animal identification number. (Modified from Scott et al., 1997.) 


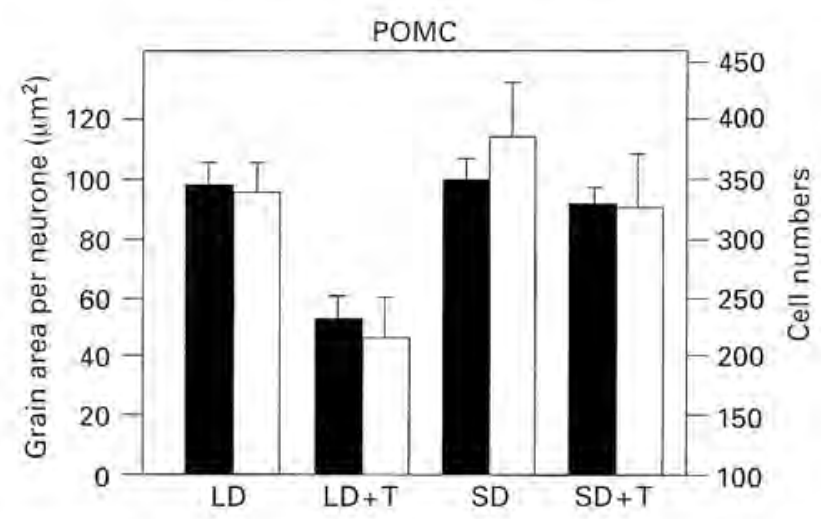

Fig. 3. Effects of testosterone (T) and duration of photoperiod on silver grain area per neurone (solid bars) and numbers of proopiomelanocortin (POMC) mRNA positive cells ( $)$ in the arcuate nucleus of castrated rams. LD: long days (16L;8D); SD; short days (10L:14D). Data are presented as means \pm SEM. POMC mRNA grain area in the $L D+T$ group was lower $(P<0.01)$ than in the other groups which did not differ from each other $(P>0.10)$. There was an effect of steroid $(P<0.05)$ and a strong tendency for an effect of photoperiod $(P=0.06)$, but no interaction of treatments $(P>0.40)$, on the number of POMC cells. (Reproduced from Hileman et al., 1998.)

arcuate nucleus of wethers kept under ambient long days. Although it is recognized that mRNA content may not always reflect actual peptide release, studies from two other laboratories independently investigating the effects of feed restriction on POMC mRNA content and $\beta$ endorphin release indicate that relative steady-state amounts of POMC mRNA are indicative of relative hypothalamic $\beta$-endorphin release rates in the lateral median eminence of sheep (Prasad et al., 1993; McShane et al., 1993). In addition, preliminary data from our recent studies using portalcannulated males indicate that naloxone effectively increases GnRH and LH release in castrated males exposed to inhibitory long days. This finding suggests that the magnitude of response to naloxone may be dependent more on the basal LH secretory rate than on steroid background. These findings support the concept that the increased synthesis of $\beta$-endorphin is not a mechanism whereby testosterone suppresses GnRH release in animals exposed to long days. It is noteworthy that Goodman et al. (1995) reached a similar conclusion regarding the relationship between oestrogen, the opiates, and LH secretion in ewes.

\section{Dopamine}

Dopaminergic neurones are clumped into nuclei or groups scattered throughout the brain. Small groups designated A12, A14, A15, and located in the anterior part of the hypothalamus appear to have a significant role in regulating $\mathrm{LH}$ in sheep. The A14-A15 group is located in the retrochiasmatic area; the $\mathrm{A} 12$ group is located in the arcuate nucleus-median eminence region. A large body of evidence from studies using female sheep and a variety of approaches led to the concept that dopaminergic input from these areas inhibits LH secretion, at least when the animals are exposed to long-day photoperiods (Thiery et al., 1995; Lehman et al., 1996; Viguie et al, 1997).

In comparison, there are relatively few studies on the role of the dopaminergic system on $\mathrm{LH}$ secretion in rams, but most of these data support an inhibitory role. Although pimozide, a dopamine 
$\mathrm{D}_{2}$ receptor antagonist, did not increase $\mathrm{LH}$ in rams (Tilbrook and Clarke, 1992), the more specific $\mathrm{D}_{2}$ antagonist sulpiride was effective in Soay rams, particularly during the non-breeding season (Tortonese and Lincoln, 1994). In addition, supporting evidence was obtained in our laboratory by monitoring the effect of testosterone administration on expression of the early-intermediate gene c-Fos in the A14-A15 cell groups. We used dual-label immunocytochemistry for c-Fos and tyrosine hydroxylase (the rate-limiting enzyme in dopamine formation) to determine the percentage of dopaminergic cells activated by testosterone. The tissue used was from our previously cited study in which we had shown that infusion of testosterone for 3 days suppressed LH release coincident with reduced POMC mRNA (Hileman et al., 1996). Testosterone treatment significantly increased the percentage of dual-labelled cells in the A15 group and strongly tended $(P<0.06)$ to increase that percentage in the A14 group. No effect of testosterone was noted on either the A13 cell group or the total number of tyrosine hydroxylase positive cells (Lubbers et al., 1995). These results are very similar to those obtained from ewes treated with oestrogen during the non-breeding season (Lehman et al, 1996). In summary, there is evidence to support the concepts (1) that activation of the A14-A15 cell groups is involved in the feedback action of gonadal steroids during the non-breeding season and (2) that during this season gonadal steroids selectively activate this dopaminergic subsystem in both rams and ewes.

\section{$G A B A$}

Gamma-aminobutyric acid (GABA) is a widely distributed neurotransmitter, the primary action of which is to inhibit the activation of other neuronal systems. Several observations indicate that it acts in the mPOA of rats to inhibit GnRH release, and results of experiments in male rats support the concept that GABA may mediate the inhibitory effect of testosterone on GnRH and LH release, particularly within the mPOA (Grattan and Selmanoff, 1993; Grattan et al., 1996; Sagrillo and Selmanoff, 1997). Results of studies in ewes also led to the contention that GABA acts in the mPOA to suppress GnRH secretion (Robinson, 1995; Scott and Clarke, 1993a,b).

Work from our laboratory supports the concept that GABA acts in both the mPOA and ARC-VMR to suppress GnRH release and within the ARC-VMR to regulate specifically LH pulse amplitude (Ferreira et al., 1996). Castrated rams had guide tubes stereotaxically placed bilaterally either in the $\mathrm{mPOA}$ or ARC-VMR to deliver drugs into these specific sites by microdialysis. Subsequently, these areas were perfused with artificial cerebrospinal fluid for $4 \mathrm{~h}$ followed by $4 \mathrm{~h}$ of either cerebrospinal fluid, the $G A B A_{A}$ receptor agonist muscimol, or the $\mathrm{GABA}_{\mathrm{B}}$ receptor agonist baclofen. In the mPOA, muscimol treatment reduced pulsatile LH release, whereas baclofen was without effect. In the ARC-VMR, muscimol also inhibited pulsatile LH release, but surprisingly baclofen actually increased LH release. This effect was due primarily to an increase in pulse amplitude rather than pulse frequency and probably reflected an increase in GnRH pulse amplitude (Fig. 4). Thus, it appears that GABA may act through the GABA receptor to suppress pulsatile GnRH release in both the POA and ARC-VMR. Interpreting the effect of baclofen is not as straightforward, but may be explained by the fact that $G_{A B A}$ receptors apparently function as autoreceptors. Local stimulation of presynaptic autoreceptors may reduce local secretion of endogenous $\mathrm{GABA}$ and thus free GnRH neurones from chronic inhibition.

Although activation of the $\mathrm{GABA}_{A}$ and $\mathrm{GABA}_{B}$ receptor subtypes obviously altered $\mathrm{LH}$ release, results from our studies addressing the issue of whether these receptor types mediate testosterone negative feedback are more difficult to interpret. The $\mathrm{GABA}_{\mathrm{A}}$ receptor antagonist bicuculline methiodide (BMI) and the GABA $\mathrm{B}_{\mathrm{B}}$ receptor antagonist CGP $55854 \mathrm{~A}$ were administered during the breeding season into only the ARC-VMR of castrated males and castrated testosterone-treated males. The expectation was that the $\mathrm{GABA}_{\mathrm{A}}$ antagonist would increase LH. However, BMI consistently suppressed $\mathrm{LH}$ release in castrated males and failed to increase $\mathrm{LH}$ secretion in the testosterone-treated males. CGP 55854A was without effect in either group. The apparently paradoxical effects of BMI might be explained by inhibitory effects of this drug on $N$-methyl-Daspartic acid (NMDA) receptors or other neurotransmitters (Svenneby and Roberts, 1973; Miller and 

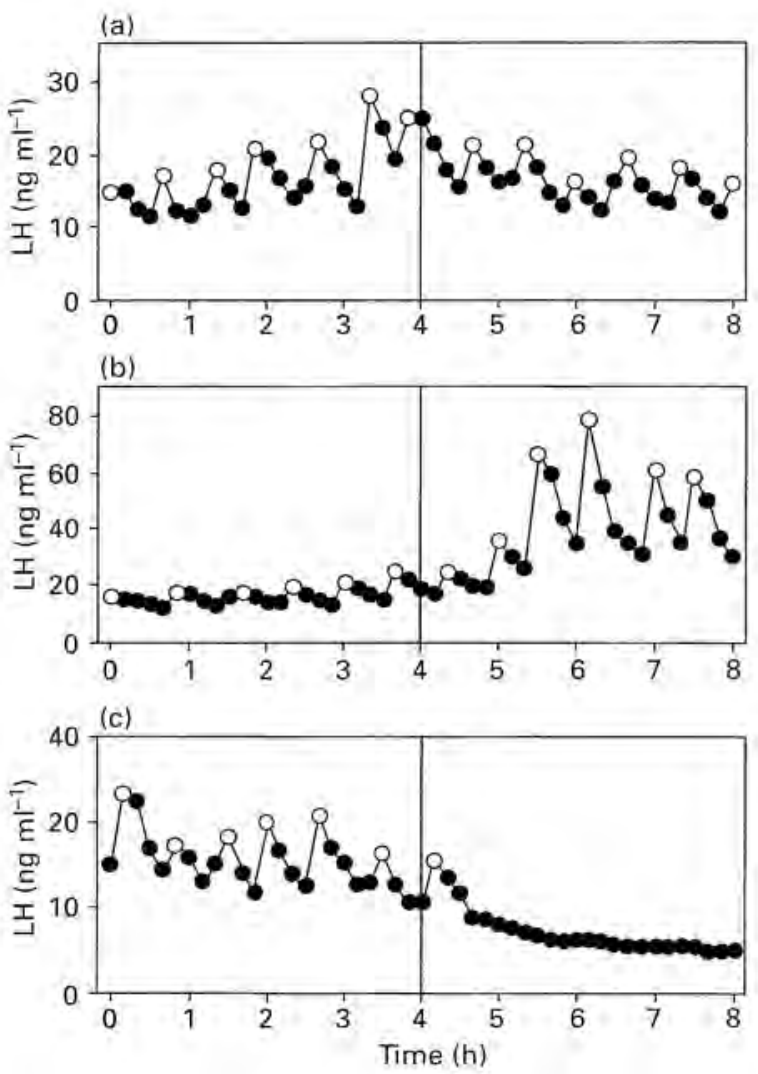

Fig. 4. Plasma LH profiles of one castrated ram subjected to separate sequential bilateral microdialysis infusion of artificial cerebrospinal fluid (aCSF) only (a), or aCSF followed by $1 \mathrm{mmol}$ baclofen $\mathrm{l}^{-1}$ (b), or aCSF (c) followed by $1 \mathrm{mmol}$ muscimol $\mathrm{H}^{-1}$ into the arcuate-ventromedial region of the hypothalamus. The drug concentrations listed are those of the dialysis solution. It is estimated that the total doses of baclofen and muscimol delivered at each site were 7.9 and $4.5 \mu \mathrm{g}$, respectively. Note the enlarged scale of the middle panel. Peaks of LH pulses are represented by hollow circles. Drug delivery started at $4 \mathrm{~h}$, as indicated by the vertical line. (Reproduced from Ferreira et al., 1996.)

McLennan, 1974; Krebs et al., 1994; Musshoff et al., 1994) and in retrospect indictaes that studies using this antagonist are interpreted with caution.

However, it should be noted that although BMI injected into the POA of ovariectomized ewes consistently reduced LH when given during the breeding season, it increased LH in some oestrogentreated ovariectomized ewes when given during the anoestrous period (Scott and Clarke, 1993b). Thus, the effect of BMI on LH may vary with steroidal background or season of treatment. Possibly, during the breeding season the GABAergic system is relatively inactive, particularly in the absence of gonadal steroids, and the only observable effect of BMI on LH secretion is inhibition due to blockade of other essential stimulatory systems attained by relatively high doses of the drug. In contrast, during the non-breeding season, when GABA activity is postulated to be increased by 


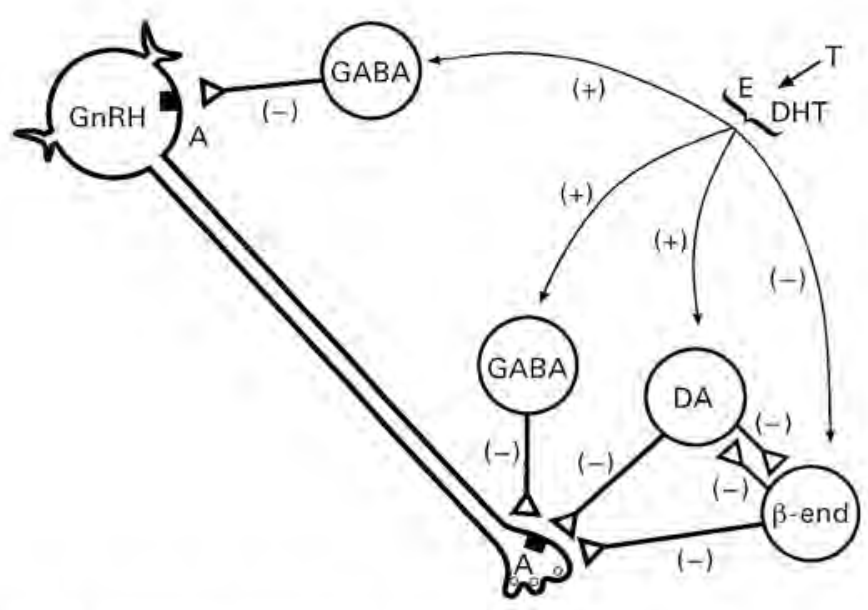

Fig. 5. Schematic illustration of the possible mechanisms by which testosterone (T) controls release of gonadotrophin-releasing hormone $(\mathrm{G} n \mathrm{RH})$ in male sheep. $(+)$ : stimulatory action; $(-)$ : inhibitory action; $\mathrm{E}$ : oestradiol, DHT; dihydrotestosterone; $\beta$-end: $\beta$ endorphin secreting neurone; DA: dopamine secreting neurone; GABA: $\gamma$-aminobutyric acid secreting neurone; $A: G A B A_{A}$ receptor.

gonadal steroids, the GABAergic system may become more sensitive to blockade. Although it is clear that GABA modulates LH secretion in rams, data are insufficient to conclude whether it partially mediates the action of testosterone on LH. Clearly, additional study will be required to resolve these issues.

\section{Summary Model}

Results of studies from several laboratories are incorporated into a summary model (Fig. 5) illustrating some of the possible neurochemical pathways by which testosterone alters GnRH release in rams. The first point is that the effects of testosterone are mediated largely, if not exclusively, by the metabolites oestrogen and DHT. These steroids act in the ARC-VMR and probably other sites to reduce GnRH pulse frequency, but not $\mathrm{GnRH}$ synthesis. A second point is that these steroids probably do not act directly on GnRH neurones, but act indirectly by modulating secretion of one or more inhibitory neuromodulators such as $\beta$-endorphin, dopamine and GABA.

The specific role of $\beta$-endorphin remains unclear, but there is overwhelming evidence that it acts tonically to inhibit GnRH release. On the other hand, it does not appear to mediate the inhibitory action of testosterone. Our results support the postulate that testosterone suppresses, not stimulates, synthesis of $\beta$-endorphin, particularly when the animals are exposed to a long-day photoperiod. It appears paradoxical that when testosterone is maximally suppressing $\mathrm{GnRH}$ release, it also is suppressing a system that inhibits GnRH release. However, the model deals with this by incorporating the possibility that testosterone also increases local dopamine release, particularly during the non-breeding season. Stimulation of dopamine release probably has two outcomes. First, DA may act directly to suppress GnRH release. Second, DA also may act to inhibit $\beta$-endorphin secretion (Tortonese and Lincoln, 1994), In our study in which testosterone suppressed POMC mRNA (Hileman et al., 1996), it also activated A14 and A15 dopamine neurones (Lubbers et al., 1995). As $\beta$-endorphin neurones contain oestrogen receptors, there may also be a direct effect of this testosterone metabolite. However, it is not clear that these associated changes reflect cause and 
effect. As indicated in the model testosterone-induced reduction in $\beta$-endorphin secretion could also secondarily lead to increased dopaminergic activity. In either case, if the inhibitory effect of dopamine on GnRH secretion is relatively stronger than that of $\beta$-endorphin, activation of this network by testosterone will still suppress GnRH release. In addition, it should be noted that the relationship among testosterone and the neurotransmitters is not static. During the breeding season the effectiveness of testosterone in altering the activity of these systems and in suppressing GnRH is reduced. Although the suppression of $\beta$-endorphin may be reduced, resulting in greater $\beta$ endorphin release, a parallel reduction in dopamine release would ultimately result in increased $\mathrm{GnRH}$ release.

In the model we suggest that $\mathrm{GABA}$ inhibits $\mathrm{GnRH}$ release by acting via $\mathrm{GABA}_{\mathrm{A}}$ receptors in both the mPOA and ARC-VMR. However, the indication that GABA partially mediates the action of testosterone is speculative.

\section{Conclusions}

There are several important unanswered questions about how testosterone reduces GnRH and LH secretion. Although oestrogen and DHT appear to mediate the action of testosterone, the relative contribution of these two metabolites is unclear. Suppression of either DHT or oestrogen formation partially blocked the inhibitory effects of testosterone on pulsatile LH release. The effect of simultaneously blocking both reductase and aromatase activities has not been determined. In addition, it is not clear exactly where in the hypothalamus or brainstem oestrogen and DHT act to alter GnRH release, Indeed, it is yet to be clearly demonstrated that DHT alters GnRH release. This issue requires further investigation, perhaps using a more androgen-responsive model than the long-term castrated male.

The specific role of the various neuromodulators remains unresolved. We are currently addressing the question of whether testosterone stimulates GABA release in the hypothalamus. However, the specific physiological roles of the GABA receptor subtypes, and the respective roles of the widely distributed GABA neurones in modulating or mediating the effects of testosterone on $\mathrm{GnRH}$ release remain to be elucidated fully in the ram.

The specific role of $\beta$-endorphin, and of other opiates, also remains elusive. It is unknown whether testosterone alters hypothalamic $\beta$-endorphin release and coincidentally whether hypothalamic release of $\beta$-endorphin reflects changes in steady state POMC mRNA. Furthermore, it is not known whether testosterone or environmental factors regulate opiate receptors, nor is it clear exactly where the opiates act. The report by Sanella et al. (1997) that GnRH neurones lack opiate receptors leads to the suggestion that still other interneurone systems must be involved - perhaps those secreting nitric oxide (Brann and Mahesh, 1997; Lopez et al., 1997).

Dopamine neurones of the A14 and A15 groups appear to be activated by testosterone during long days. Whether this is specific for an inhibitory photoperiod in males as in females is not known. The relative importance and relationship of this subset, and the A12, dopamine neurones to GnRH release has not been determined nor have efferent and afferent pathways to and from these dopamine groups. Given that the A14-A15 dopaminergic neurones apparently contain little oestrogen receptor- $\alpha$ (Lehman and Karsch, 1993) it is not clear how their function is modulated by either photoperiod or steroids.

In addition, there is a fundamental question as to how photoperiod acts to gate the sensitivity of these and possibly other systems to testosterone. Ultimately this involves melatonin, the pineal hormone which transduces photic information into a chemical signal. Although considerable progress has been made (for example Malpaux et al, 1998; Hileman et al., 1994a) neither the neuroanatomical components nor the identity of neural systems involved in this pathway are completely known. Perhaps even more perplexing is the consistent observation that although testosterone or oestrogen administration suppresses LH pulse frequency, pharmacological manipulations of various neurotransmitters have failed to mimic fully the action of either steroid treatment or removal. Consequently this leads to the suggestion that testosterone, its metabolites or 
both may act through the coordinated activity of several neurotransmitter systems rather than a single system. Thus, it seems likely that much effort will be required before we fully understand the 'relatively simple' pathways by which testosterone regulates $\mathrm{GnRH}$ and $\mathrm{LH}$ release in males before those by which environmental factors modulate the action of testosterone can be determined.

The authors gratefully recognize the contributions of our colleagues Suzie Ferreira, David Kuehl, Laura Lubbers, and Chris Scott who contributed to the work from this laboratory. These studies were supported by NIH Grant HD 27453 and USDA Grants AG92-37203-8177 and AG95-37203-2033.

\section{References}

Barb CR, Kraeling RR and Rampacek GB (1991) Opioid modulation of gonadotropin and prolactin secretion in domestic farm animals Domestic Animal Endocrinology 8 15-27

Belsham DD, Evangelou A, Roy D, Le DV and Brown TJ (1998) Regulation of gonadotropin-releasing hormone (GnRH) gene expression in GnRH-secreting GT1-7 hypothalamic neurons Endocrinology 139 1108-1114

Brann DW and Mahesh VB (1997) Excitatory amino acids: evidence for a role in the control of reproduction and anterior pituitary hormone secretion Endocrine Reviews 18 $678-700$

Caraty A and Locatelli A (1988) Effect of time after castration on secretion of LHRH and LH in the ram Journal of Reproduction and Fertility 82 263-269

Ebling FJP and Lincoln GA (1985) Endogenous opioids and the control of seasonal LH secretion in Soay rams Tournal of Endacrinology 107 341-353

Ferreira SA, Scott CJ, Kuehl DE and Jackson GL (1996) Differential regulation of futeinizing hormone release by "\% aminobutyric acid receptor subtypes in the arcuateventromedial region of the castrated ram Endocrinology 137 3453-3460

Ferreira SA, Hileman SM, KuehL DE and Jackson GL (1998) Effects of dialyzing $\gamma$-aminobutyric acid receptor antagorists into the medial preoptic and arcuate ventromedial region on luteinizing hormone release in male sheep Biology of Reproduction 58 1038-1046

Goodman RL, Parfitt DB, Evans NP, Dahl GE and Karsch FJ (1995) Endogenous opioid peptides control the amplitude and shape of GnRH pulses in the ewe Endocrinotogy 136 2412-2420

Grattan DR and Selmanoff M (1993) Regional variation in y-aminobutyric acid turnover: effect of castration on $\gamma$-aminobutyric acid turnover in microdissected brain regions of the male rat Journal of Neurochemistry 60 2254-2264

Grattan DR, Rocca MS, Sagrillo CA, McCarthy MM and Selmanoff M (1996) Antiandrogen microimplants into the rostral medial preoptic area decrease $\gamma$-aminobutyric acidic neuronal activity and increase luteinizing hormone secretion in the intact male rat Endocrinology 137 4167-4173

Handa RJ, Kerr JE, DonCarlos LL, McGivern RF and Hejna G (1996) Hormonal regulation of androgen receptor messenger mRNA in the medial preoptic area of the male rat Molecular Brain Research 39 57-67

Herbison AE (1995) Neurochemical identity of neurones expressing oestrogen and androgen receptors in sheep hypothalamus Journal of Reproduction and Fertility Supplement $49271-283$
Hileman SM, Kuehl DE and Jackson GL (1994a) Effect of anterior hypothalamic area lesions on photoperiod-induced shifts in reproductive activity of the ewe Endocrinology 135 1816-1823

Hileman SM, Labbers LS, Kueh1 DE, Schaeffer DJ, Rhodes L and Jackson GL (1994b) Effect of inhibiting $5 \alpha$-reductase activity on the ability of testosterone to inhibit luteinizing hormone release in male sheep Biology of Reproduction 50 $1244-1250$

Hileman SM, Lubbers LS, Petersen SL, Kuehi DE, Scott CJ and Jackson GL (1996) Influence of testosterone on LHRH release, LHRH mRNA and proopiomelanocortin mRNA in male sheep Journal of Neuroendocrinology 8 11.3-121

Hileman SM, Kuehl DE and Jackson GL (1998) Photoperiod affects the ability of testosterone to alter proopiomelanocortin mRNA, but not luteinizing hormonereleasing hormone mRNA, levels in male sheep Ioninal of Neuroendocrinology $10587-592$

Huang $X$ and Harlan RE (1993) Absence of androgen receptors in LHRH immunoreactive neurons Brain Research 624 309-311

Jackson GL, Kuehl D and Rhim TJ (1991) Testosterone inhibits gonadotropin-releasing hormone pulse frequency in the male sheep Biology of Reproduction 45 188-194

Kalra SP and Kalra PS (1989) Do testosterone and estradiol-17ß enforce inhibition or stimulation of luteinizing hormonereleasing hormone Biology of Reproduction $41559-570$

Krebs MO, Kemel ML, Gauchy C, Desban M and Glowinski J (1994) Does bicuculline antagonize NMDA receptors? Further evidence in the rat striatum Brain Research 634 345-348

Lehman MN and Karsch F (1993) Do gonadotropin-releasing hormone, tyrosine hydroxylase-, and beta-endorphinimmunoreactive neurons contain estrogen receptors? A double-label immunocytochemical study in Suffolk ewes Endocrinology $133887-895$

Lehman MN, Ebling FJP, Moenter SM and Karsch F] (1993) Distribution of estrogen reçeptor-immunoreactive cells in sheep brain Endocrinology 133 876-886

Lehman MN, Durham DM, Jansen HT, Adrian B and Goodman RL (1996) Dopaminergic A14/A15 neurons are activated during estradiol negative feedback in anestrous, but not breeding season, ewes Endocrinology 137 4443-4450

Leranth C, MacLusky NJ, Shanabrough M and Naftolin F (1988) Immunohistochemical evidence for synaptic connections between pro-opiomelanocortin-immunoreactive neurons and LH-RH neurons in the preoptic area of the rat Brain Research 449 167-176

Lopez JL, Moretto M, Merchenthaler I and Negro-Vilar A (1997) Nitric oxide is involved in genesis of pulsatile LHRH 
secretion from immortalized LHRH neurons journal of Neuroendocritology 9 647-654

Lubbers LS, Hileman SM, Jansen HT, Lehman MN and Jackson GL (1995) Testosterone-induced activation of tyrosine hydroxylase-containing neurons of the A14 and A15 hypothalamic nuclei in the male sheep Abstracts 25 th Annual Meeting, Society for Neuroscience Abstract 745 2, p 1897

McShane TM, Petersen SL, McCrone S and Keisler DH (1993) Influence of food restriction on neuropeptide $Y$, proopiomelanocortin, and luteinizing hormone-releasing hormone gene expression in sheep hypothalami Biology of Reproduction $49831-839$

Malpaux B, Daveau A, Maurice-Mandon F, Duarte G and Chemineau P (1998) Evidence that melatonin acts in the premanillary area to control reproduction in the ewe: presence of binding sites and stimulation of LH secretion by in situ microimplant delivery Endocrinology 139 1508-1516

Miller JJ and McLennan H (1974) The action of bicuculline upon acetylcholine-induced excitations of central neurons Neuropharmacology 13 784-785

Monet-Kuntz C, Hochereau-deReviers MT, Pisselet C, Perreau C, Fontaine I and Schanbacher BD (1988) Endocrine parameters, hormone receptors, and functions of the testicular interstitium and seminiferous epithelium in estradiolimmunized Il-de-France rams Journal of Andrology 9 278-283

Musshoff U, Majeda M, Bloms-Funke P and Speckmann E- (1994) Effects of epileptogenic agent bicuculline methiodide on membrane currents induced by $\mathrm{N}$-methyl-D-aspartate and kainate (oocyte:Xenopus laevis) Brain Research 639 135-138

Naftolin F and Ryan KJ (1975) The metabolism of androgens in central neuroendocrine tissues Journal of Steroid Biochemistry $6993-997$

Parrott RF and Davies RV (1979) Serum gonadotropin levels in prepubertally castrated male sheep treated for long periods with propionated testosterone, dihydrotestosterone, 19. hydroxytestosterone or oestradiol Journal of Reproduction and Fertility $56543-548$

Prasad BM, Conover CD, Sarkar DK, Rabji J and Advis JP (1993) Feed restriction in prepubertal lambs: effect on puberty onset and on in vivo release of luteinizing hormone-releasing hormone, neuropeptide $Y$ and beta-endorphin from the posterior-lateral median eminence Neuroendocrinology 57 1171-1181

Rhim T, Kuehl D and Jackson GL (1993) Seasonal changes in the relationships between secretion of gonadotropin-releasing hormone, luteinizing hormone, and testosterone in the ram Biology of Reproduction 48 197-204

Robinson JE (1995) Gamma amino-butyric acid and the control of GnRH secretion in sheep Journal of Reproduction and Fertility Supplement 49221-230

Sagrillo CA and Selmanoff M (1997) Castration decreases single cell levels of mRNA encoding glutamic acid decarboxylase in the diagonal band of broca and the sexually dimorphic nucleus of the preoptic area Journal of Nentoendocrinology 9 699-706

Sannella MI and Petersen SL (1997) Dual label in situ hybridization studies provide evidence that luteinizing hormone-releasing hormone neurons do not synthesize messenger ribonucleic acid for mu, kappa, or delta opiate receptors Endocrinology 138 1667-1672

Schanbacher BD (1984) Regulation of luteinizing hormone secretion in male sheep by endogenous estrogen Endocrinology $115944-950$
Scott CJ and Clarke IJ (1993a) Inhibition of LH secretion in ovariectomized ewes during the breeding season by gamma-aminobutyric acid (GABA) is effected by $G A B A$, receptors, but not by $\mathrm{GABA}_{\mathrm{B}}$ receptors Endoctinology 132 $1789-1796$

Scott CJ and Clarke If (1993b) Evidence that changes in the function of the subtypes of the receptors for $\psi$ aminobutyric acid may be involved in seasonal changes in the negative-feedback effects of estrogen on gonadotropinreleasing hormone secretion and plasma luteinizing hormone levels in the ewe Endocrinology 133 2904-2912

Scott CJ, Kuehl DE, Ferreira SA and Jackson GL (1997) Hypothalamic sites of action for testosterone, dihydrotestosterone, and estrogen in regulation of luteinizing hormone secretion in male sheep Endocrinology 138 3686-3694

Selmanoff MK, Brodkin LD, Weiner RI and Sitteri PK (1977) Aromatization and $5 \alpha$-reduction of androgens in discrete hypothalamic and limbic regions of the male and female rat Endocrinology 101 841-848

Shen ES, Meade EH, Perez MC, Deecher D, Negro-Vilar A and Lopez FJ (1998) Expression of functional estrogen receplors and galanin messenger ribonucleic acid in immortalized luteinizing hormone-releasing neurons: estrogenic control of galanin gene expression Endocrinology $139939-948$

Shivers BD, Harlan RE, Morrell JI and Pfaff DW (1983) Absence of oestradiol concentration in cell nuclei of LHRHimmunoreactive neurones Nature 304 345-347

Shugrue PJ, Lane MV and Merchenthaler I (1997) Comparative distribution of estrogen receptor $\alpha$ and $-\beta m R N A$ in the rat central nervous system Journal of Comparative Neurology $388507-525$

Ssewannyana E and Lincoln GA (1990) Regulation of photoperiod-induced cycle in the peripheral blood concentrations of $\beta$-endorphin and prolactin in the ram: role of dopamine and endogenous opioids foumal of Endocrinology 127 461-469

Svenneby G and Roberts E (1973) Bicuculline and Nmethylbicuculline-competitive inhibitors of brain acetylcholinesterase journal of Neurochemistry 21 1025-1026

Thiery J-C, Gayrard V, LeCorre S, Viguie C, Martin GB, Chemineau P and Malpaux B (1995) Dopaminergic control of LH secretion by the A15 nucleus in anoestrous ewes Journal of Reproduction and Fertility Supplement 49 285-296

Thind KK and Goldsmith PC (1988) Infundibular gonadotropinreleasing hormone neurons are inhibited by direct opioid and autoregulatory synapses in juvenile monkeys Neuroendocrinology 47 203-216

Tilbrook AJ and Clarke IJ (1992) Evidence that dopaminergic neurons are not involved in the negative feedback effect of testosterone on luteinizing-hormone in rams in the nonbreeding season Journal of Neuroendocrinology 4 365-374

Tilbrook AJ and Clarke IJ (1995) Negative feedback regulation of the secretion and actions of GnRH in male ruminants Journal of Reproduction and Fertility Supplement 49 297-306

Tortonese DJ and Lincoln GA (1994) Photoperiodic modulation of dopaminergic control of pulsatile LH secretion in sheep Journal of Endocrinology 143 25-32

Viguie C, Thibault J, Thiery JC, Tillet $\mathrm{Y}$ and Malpaux B (1997) Characterization of the short day-induced decrease in median eminence tyrosine hydroxylase activity in the ewe: temporal relationship to the changes in luteinizing hormone and prolactin secretion and short day-like effect of melatonin Endocrinology 138 499-506 